\title{
The relationship between man and cosmos: the contribution of Isaac Israeli
}

\author{
Prof. PhD. Encarnación Ruiz CALLEJÓN \\ Faculty of Philosophy, University of Granada \\ SPAIN, \\ E-mail: ruizencarnacion@ugr.es
}

\begin{abstract}
The purpose of this work is to analyse the contribution of the Jewish doctor Isaac Israeli to the medieval reflection on the relationship between man and the cosmos. To this end, starting from the methodological change proposed by al-Yabri for the study of classical Arabic philosophy, I question the usual characterization of the Jewish author as being merely an eclectic thinker, and indicate the most noteworthy aspects of his position. The philosophical texts that have come down to us reveal a philosopher who participates in the great debates of his time, among them: the relation between philosophy and revelation and the nature of the human intellect. Beyond the prophetic aspect, Israeli points to a special logic based on the ability to argue evoking images, a universal way that facilitates the compression of a complex idea or promotes the performance of an action.
\end{abstract}

Keywords: Arabic Philosophy; Medieval Jewish Philosophy; Neoplatonism; Prophecy;

\section{INTRODUCTION}

We hardly have any information on Isaac Israeli ${ }^{1}$, also known as Isaac Judaeus ${ }^{2}$ or Isaac the Elder, in order to differentiate him from the 14th century Hispanic astronomer. $\mathrm{He}$ was born in Egypt between 830 and 850 ${ }^{3}$, and died between 932 and 955/956. He was called to Kairuán, capital of modern Tunisia, as a court physician. Already a prestigious practitioner, he met the young Saadia Gaon, with whom he exchanged correspondence on scientific and philosophical topics. Israeli would have also dedicated himself to astronomy, research into the Hebrew language and Biblical exegesis ${ }^{4}$. He is considered the first Neoplatonic Jewish philosopher ${ }^{5}$ and one of the first Jewish philosophers of the Medieval period. But his fame as a physician would have been decisive for the discreet disclosure of his philosophical work $^{6}$, considered as a mere compilation lacking originality ${ }^{7}$. On the

[1] Abū Ya'qūb Isḥāq ibn Sulaymān al-Isrā'îlī. The author's patronymic, Abū Ya'qūb, which does not necessarily indicate his paternity, is provided by, for example, Ibn Abī Ușaibi'a.

[2] To differentiate him from the 14th century Hispanic astronomer, also called Isaac Israeli.

[3] Raphaela Veit, Das Buch der Fieber des Isaac Israeli und seine Bedeutung im lateinischen Wester. Ein Beitrag zur Rezeption arabischer Wissenschaft im Abendland, Franz Steiner Verlag, München, 2003, p. 25.

[4] Salomon Fried, Das Buch über die Elemente. Ein Beitrag zur jüdischen Religionsphilosophie des Mittelalters, Verlag von J. Kauffmann, Frankfurt a. M., 1900, pp. 26-27.

[5] And the first Medieval, if we exclude al-Muqamis, who lived between 820 and 890, and who we still know very little about. We have the publication, translation and notes of Sarah Stroumsa, Dāwud ibn Marwān alMuqamis's Twenty Chapters ('Ishrūn Maqāla). Études sur le judaïsme médiéval XIII, Brill, Leiden, 1989.

[6] Julius Guttmann, Philosophies of Judaism. A History of Jewish Philosophy from Biblical Times to Franz Rosenzweig. Introduction by R. J. Zwi Werblowsky. Translated by David W. Silverman, Schocken Books, 1976, New York, p. 96. 
following pages, I would like firstly to focus on some aspects that highlight the above assessment and, secondly, on significant aspects of his conception of philosophy and prophecy concerning the relationship between man and the cosmos and the configuration of knowledge. I believe this second part would allow for the inclusion of the author in the philosophical tradition which analyses the conditions of the prophecy and its meaning as a channel for knowledge transfer.

\section{A COMPILER AND MERELY A GREAT PHYSICIAN}

It should firstly be pointed out that the previous assessment which usually appears also in the combined works does not entirely depend on the analysis of the thought of Isaac Israeli, as a number of his works have only come to us in fragments, and others simply have not been conserved. We know little about his training and nothing in the case of philosophy ${ }^{8}$. His style of writing and argumentation doesn't help the interpretation, either. Secondly, the majority of the research carried out dates from the era of the translation into English of his philosophical work, that is, $1958^{9}$. In addition to the question relating to his birth and death dates, various have been proposed for the latter $(932,953,955-6)$, with a domination of the search for sources which, being absolutely necessary, has however contributed to excluding direct readings on the part of the author, as well as the exposition of original ideas ${ }^{10}$. In an attempt to determine these sources, a series of works has been considered, including:

[7] This is the opinion, for example, of Guttmann: "Als philosophischer Schriftsteller ist Israeli ein bloßer Kompilator geblieben" (Jacob Guttmann, Die philosophischen Lehren des Isaak ben Salomon Israeli, Aschendorffsche Verlagsbuchhandlung, Münster i. W., 1911, p. 5). And also of Isaac Husik, although he stresses that the author lacked the ambition to create a system, and underlines his main achievement as having attracted the attention of Jews towards Greek thought and science, although within an Arabic context (Isaac Husik, A History of medieval Jewish philosophy, The Macmillan Company, New York, 1918, p. 16). Colette Sirat refers to him as the first writer, after Philo of Alexandria, to integrate philosophical ideas extracted directly from Greek sources into Jewish thought. His thought would offer us an exposition of a Neoplatonic Jewish philosophy. She adds that the importance of Israeli is in being the first Medieval Jewish "philosopher", although his influence on later Jewish philosophers was limited (Colette Sirat, A History of Jewish philosophy in the Middle Ages, Cambridge University Press y La Maison des Sciences de l'Homme, Cambridge, 1977, pp. 57-58).

[8] Stern affirms that the problem would be solved if it could be assumed that the Ishāq ibn Sulaymān mentioned by Hunayn ibn Isḥāq were identical to our Ishāa ibn Sulaymān. Hunayn, in a list of his translations of works by Galeno, speaks of four of his translations that were done by "Ishāq ibn Sulaymān". If it is the same person, this information could widen the perspective on Israeli's contacts with the scholars of Baghdad. But it is more likely that Ishāq ibn Sulaymān is identical to the noted Muslim of the same name who was, for a time, Governor of Egypt (S. M. Stern, "Introduction". Note 2, in A. Altmann, S. M Stern. Isaac Israeli: a neoplatonic philosopher of the early tenth century. His works translated with comments and an outline of his Philosophy, Oxford University Press, Oxford, 1958, pp. xxi-xxii).

[9] A. Altmann, S. M Stern. Isaac Israeli: a neoplatonic philosopher. In this version of Israeli's works, the participation of the researchers is distributed as follows: Stern is responsible for the biographical note and translates and comments on the Book of Definitions, the Book of Substances and the Book on Spirit and Soul. Altmann, the Mantuan Text and the passage from the Book of the Elements. The study of the philosophy of Israeli is carried out by Altmann. I will quote the works of Israeli in the following manner: author, title of the work, paragraph or fragment $(\S)$, number of paragraph or fragment, and page corresponding to the English version. Comments, preliminary notes, etc. by the editors will be quoted as follows: name of the comment author, title of the section in question and page.

[10] An extreme example is how Altmann explains Israeli's interest in the topic of creation out of nothing due to the influence of al-Kindī who, in turn, would have taken it from Islamic Neoplatonic authors. However, creation out of nothing is naturally associated with Judaism, like the rest of the monotheisms (A. Altmann, "The philosophy of Isaac Israeli", in A. Altmann and S. M Stern, Isaac Israeli: a neoplatonic philosopher, p. 152). 
compilations of the Enneads; the short version of the so-called Theology of Aristotle and the fragments of the long version; the Epistles of the Brethren of Purity and the PseudoEmpedoclean Book of the Five Substances. But these works themselves refer to diverse influences, representing rather a reference framework from the era, and some are even after Israeli. The publishers of his work into English have indicated two fundamental influences on our philosopher ${ }^{11}$ : al-Kindī, especially in the Book of Definitions, and a Neoplatonic treatise possibly attributed to Aristotle, now lost, about which we know nothing of either the author or the title ${ }^{12}$. Another added question is the lack of further research into the direct or indirect influence of Israeli's work. He is quoted in El fin del sabio (The purpose of the wise man), an Andalusi work from the 11th century ${ }^{13}$. Moses ibn Ezra uses the Book of definitions and refers to a lost treatise by the author. His influence has also been mentioned in Josef ibn Saddī ${ }^{14}$, in Saadia Gaon, in ibn Gabirol ${ }^{15}$ and in the circle of Jewish mystics of Gerona. In the Latin context, his work was known and had a direct influence on Domingo Gundisalvo, Albertus Magnus, Thomas Aquinas (who incorrectly attributes the theory of truth as correspondence to him), Vincent of Beauvais, Buenaventura, Roger Bacon and Nicholas of Cusa $^{16}$. We also know he had Jewish and Muslim disciples ${ }^{17}$.

Thirdly, a factor to consider, not least, is the repercussion of the known letter from Maimonides to Samuel ibn Tibbon. Amongst the authors that advised against it we find Israeli, who he doesn't consider a philosopher as such. The Book of Definitions and the Book of Elements seem "unrealistic, conceited, and vain"18. According to Harvey" ${ }^{19}$, the recommendations of the philosopher from Cordoba were decisive when deciding that he was

[11] "Thus for the proper understanding of the Book of Substances, as well as of the Book on Spirit and Soul and the Mantua Text, an acquaintance with Ibn Hasdāy is necessary" (S. M Stern. "Comments", in A. Altmann and S. M Stern, Isaac Israeli: a neoplatonic philosopher, p. 96).

[12] Stern calls it Ibn Hasdāy's Neoplatonist and attempts to reconstruct the treatise in a 1960 work published in the magazine Oriens: S. M. Stern, "Ibn Hasdāy's, Neoplatonist. A Neoplatonism Treatise and its influence on I. Israeli and the longer version of the Theology of Aristotle", in Oriens 13, (1960-1961), pp. 58-120.

[13] Cf. S. M. Stern, "Biographical Note", in A. Altmann and S. M Stern, Isaac Israeli: a neoplatonic philosopher, pp. xii-xiv.

[14] In relation to this influence Stern asserts: "The eschatology of Israeli (combined with elements derived from other sources) recurs in the Microcosm of Joseph ibn Saddīq" (S. M. Stern, "Comments". Note I, in A. Altmann and S. M Stern, Isaac Israeli: a neoplatonic philosopher, p. 117).

[15] "How far Solomon ibn Gabirol, the greatest among the Jewish Neoplatonists, is indebted to Israeli is a question which still requires detailed investigation" (S. M. Stern, "Biographical Note", in A. Altmann and S. M Stern, Isaac Israeli: a neoplatonic philosopher, p. 152). Fried refers to the philosophy within Judaism and a significant number of authors, apart from those mentioned, which Israeli would have influenced: Sabbatai Donnolo, the first doctor and philosopher in the west to write in Hebrew, Ibn Paqūda, Yěhudah ben Šemu'el ha-Levi and Abraham ibn Daud (Salomon Fried, Das Buch über die Elemente, pp. 55-75).

[16] Jacob Guttmann, Die philosophischen Lehren.

[17] Israeli's disciples were the Muslim Ibn al-Jazzār, Abū Ja'far Ahmad ibn Ibrāhīm ibn Abī Khālid, the author of a manual of medicine translated by Constantine the African as Viaticum peregrinantis, and the Jew, Dūnaš ibn Tamīm. The latter would have succeeded him as court physician. According to Fried, Dūnaš ibn Tamīm didn't practice medicine, rather he studied philosophy, astronomy, mathematics and exegesis with Israeli (Salomon Fried, Das Buch über die Elemente, p. 20).

[18] “...the Sefer ha-gebulim (Book of Definitions) and the Sefer ha-yesodot (Book of Elements) composed by Isaac Israeli, are equally unrealistic, conceited and vain, because Isaac Israeli was also [previously, Abū Bakr al-Rāzī's was also referred to in the same sense] just a doctor (...) (Carlos del Valle (ed.), Letters and testimony of Maimonides (1138-1204). III Letter of R. Shemuel Ibn Tibbón, Publicaciones del Monte de Piedad y Caja de Ahorros de Córdoba, Córdoba, 1989, p. 34).

[19] Steven Harvey, "Did Maimonides' letter to Samuel ibn Tibbon determine which philosophers would be studied by later Jewish thinkers?", in The Jewish Quarterly Review. Vol. LXXXIII (july-october 1992), pp. 5657. 
worthy of being studied and, above all, translated. Luckily, the Book of Definitions had previously been translated and in the 13th century, David Qimhī, a famous biblical commentator, asks ibn Hasdāy to translate the Book of Elements, who for his part laments that the philosophy of Israeli has been forgotten amongst Jews who don't speak Arabic. In Harvey's opinion, ibn Hasdāy's circle would represent a work programme and a conception of knowledge favourable to Neoplatonism. This was the framework and the horizon for the Jewish intellectuals of the 11 th and 12 th centuries ${ }^{20}$, capable of bringing together a great variety of components and of conciliating the two great Greek philosophers with monotheism. Samuel ibn Tibbon, on the contrary, shared Maimonides' guidelines, which furthermore ended up triumphing: translation of Aristotelian work, of his commentators and of works of mathematics, astronomy and medicine ${ }^{21}$.

Furthermore, apart from the pretension of originality not being a value in the period and, even less so, an objective, we also face one of the typical criticisms of medieval philosophy in general ${ }^{22}$ : its eclectic condition of transmission and repetition as regards the Greek contributions. Along the line of a similar assessment, but in this case of classical Arabic philosophy, the now disappeared Moroccan philosopher, al-Yabri, proposed a change in the study of this line of thinking motivated by both "methodological imperative", and by the demand itself for the "reality of philosophical thought in the Islamic world"23. This methodological change, based on effective, and not on projected or demanded history, would consist in analysing Arabic philosophy firstly from its own contemporaneity, as the perspective adopted up to this point - impose a past and some unrelated cultural keys upon it - could do nothing other than distort it, such as has occurred, and lead to the conclusion that, in effect, Arabic philosophy has been a copy, or even a bad copy, of Greek philosophy ${ }^{24}$. To this end, Al-Yabri indicated the need to distinguish between what he calls the cognitive component and ideological content ${ }^{25}$ of a work or a thought. The cognitive component is

[20] Tamar M., Rudavsky, "Medieval Jewish Neoplatonism”, in Daniel H., Frank and Oliver Leaman (eds.), Routledge History of World Philosophies. Vol. II: History of Jewish Philosophy, Routledge Press, London and New York, 1974, p. 149. Colette Sirat, A History of Jewish philosophy, p. 57.

[21] "This meant a seemingly concerted effort to translate the entire Aristotelian corpus, or more precisely, all the Averroean commentaries on Aristotle and some commentaries of Alexander of Aphrodisias and Themistius, ancillary writings of the Muslim Aristotelians- especially al-Fārābī and Averroes- and the most important texts on mathematics, astronomy, and medicine. This agenda, which I have suggested was somehow defined by Maimonides' letter to Ibn Tibbon, afforded little time for the luxury of translating "optional reading", such as the Neoplatonic writings" (Steven Harvey, "Did Maimonides' letter to Samuel ibn Tibbon", pp. 65-66).

[22] The possible utility of the texts of the Jewish thinkers is still added to this critique for discovering the intellectual scene of his era, or to complete the knowledge, but of other authors: "The Jewish thinkers, though not remarkable for the originality of their ideas, introduce us to the intellectual climate of their age, and its possible that quotations from unknown authors occasionally occur in their works" (Colette Sirat, A History of Jewish philosophy, p. 57).

[23] Mohamed Abed Yabri, El legado filosófico árabe: Alfarabi, Avicena, Avempace, Averroes, Abenjaldún: Lecturas contemporáneas, Trotta, Madrid, 2006, p. 42.

[24] It is excessive to indicate the intrinsic diversity of Greek knowledge, and other sometimes forgotten aspects of it: "Neither the Greeks or those from the Middle East ever knew the limits between Europe and the East, between the West and the Middle East. Our great culture is born and matures in this unitary corner without borders, which is Egypt, Babylon, Persia, Greece. (...) The great philosophy and science, upon which we boast of basing our rationalism and culture, are not born on the Hellenic Peninsula, but the Colonies of Asia Minor (...). And it will be necessary to wait for Socrates for the first Athenian philosopher. And it must be taken into account that all of these colonies had been Persian cities until very recently (up to $500 \mathrm{BC}$, more or less), with the Persian border then being few kilometres from these centres" (Joaquín Lomba, "The agonies of 'eurocentrism,", in Éndoxa: Series Filosóficas 12 (2000), pp. 82-83).

[25] Mohamed Abed Yabri, El legado filosófico árabe, p. 41. 
comprised of the materials with which the work or thought is formed (concepts, for example). The ideological content is the socio-political function of such materials, or in other words, their application, to which the philosopher or the work in question has wished to respond, to which challenge or problem they were attempting to overcome. The key is in the fact that it is not necessary for both aspects, the cognitive and the ideological, to coincide, as a single material can be used for very different ends, in the same way as we erect very different buildings with the same construction materials. Taking this methodological approach into account, according to Yabri, the Islamic philosophers would not have been interested in developing the inherited cognitive material, that which they take from the Greeks, rather in using it according to the needs of their social and political context ${ }^{26}$. As Lomba indicates, they didn't read the Greeks to transfer their thought to anyone, rather for their own scientific interest, and to enrich their culture. The ideological (socio-political) function "is only revealed attending to their thought itself" 27 , even considering that which it was aimed at. The fact is that we would be facing the same situation, the same philosophical path, the same conception of what philosophy was in the Hellenist and Medieval Christian period: "The cognitive material employed in philosophical thought remained unaltered: it only changed the way in which this material was ideologically exploited"28, and this just means, what was it used for, and for what purpose? In classical Arabic philosophy, which is the objective of al-Yabri's reflection, we would then be facing a thought in action and a militant discourse:

\begin{abstract}
"Muslim philosophers were interested in religion being accepted by reason and reason legitimated in the eyes of religion, and not to approach unexplored horizons from new grounds. This made Islamic philosophy into a continuous ideological discourse (...) What Islamic philosophy contributes as new should be sought not in the group of knowledge that it caused to flourish and disseminated, but in the ideological function that each philosopher attributed to this knowledge" ${ }^{29}$.
\end{abstract}

And in each one of the authors analysed by Yabri, he indicates how and why philosophy has been an "ideological and militant discourse committed to science, development and progress" $" 30$.

In reality, what the Moroccan philosopher proposes to us is merely to be an honest reader, an interpreter who by reading does justice to the text tackled and is capable of articulating hermeneutics not only from critique and suspecting but from listening, as Paul Ricoeur says. I believe that in the case of Isaac Israeli, we would then need consider researching the ideological content, the objective of the works of our author, including his concept of Neoplatonism: a metaphysics of light and shadow, the conciliation of the emanation of the revelation and a conception of evil distinct from privation and identification with the material, and with a theory of the causality that models ex nihilo creation and includes a naturalist explanation of the sublunary world, not exempt from hints of mysticism. In addition, the interest of the Neoplatonic system for Fatimid Islam is not excluded, as according to some sources Israeli wrote his treatises ${ }^{31}$ at the behest of the governor. We are also in the dark about the possible teaching activity of the philosopher.

[26] Joaquín Lomba, “The agonies of 'eurocentrism' ”, p. 13.

[27] Mohamed Abed Yabri, El legado filosófico árabe, p. 42.

[28] Mohamed Abed Yabri, El legado filosófico árabe, p. 45.

[29] Mohamed Abed Yabri, El legado filosófico árabe, pp. 45-46.

[30] Mohamed Abed Yabri, El legado filosófico árabe, p. 48.

[31] S. M. Stern, in A. Altmann and S. M Stern, Isaac Israeli: a neoplatonic philosopher, p. xx. 
Maybe some of his works have this purpose. Furthermore, the contribution of Israeli should also be assessed in light of his work as a pioneer:

"It may be that this lack of originality is, to some extent, inherent in his status as the man who introduced philosophy and science into his cultural circle, where it was too early to generate new ideas" 32 .

It is not possible to reject the philosophical framework that dominates his medical production, either:

\begin{abstract}
"Regarding Book on Fevers specifically and the aspects of the work analysed here, it is apparent that Isaac Israeli considered the first treatise a work of philosophy and saw the rest as a medical text. By combining them in a single work, Israeli made it clear - and with more conviction than later authors - that medicine was a skill rooted in philosophy and based on philosophy, and he expressed that distinctly in his classification of the science, ${ }^{, 33}$.
\end{abstract}

We must not forget, either, that in recommendation 14 of his Propaedeutics for Physicians, it affirms that the doctor must establish the foundations of his science in natural philosophy and to this end it was essential to refer to the scientific framework and the intellectual horizon of the era: Neoplatonism. All of these questions rest importance from the first, and most partial assessment of the author.

\title{
2. PHILOSOPHY AND ITS DISCOURSE
}

It is not my intention to offer a solution to what would be the ideological content of the philosophical works of Israeli. It is not possible taking into account the conserved texts and the secondary information available to us today. But I do believe that indications can be made separately from this problem, highlighting some aspects of his idea of philosophy in relation to his method and prediction. The philosophical works that have come to use, partially in some cases, are: the Book of Definitions, the Book of Substances, the Book on Spirit and Soul, the Chapter on the Elements or Mantuan Text, and the Book of the Elements. The sources also attribute a work on metaphysics (Garden of Wisdom) and an introduction to logic. According to Ibn Ğulğul, Israeli would have been a doctor with a gift for the word and familiarised with the art of discourse. Stern interprets this detail as an allusion to the style of his medical documents. Perhaps he also refers to some of Israeli's professional profile features when treating patients, to his communication skills. Șaid states that he was an expert in logic and a scholar in all branches of knowledge, maybe interpreting the allusion of Ibn Ğulğul to Israeli's gift for speaking. Israeli’s Propaedeutics for Physicians reveals his appreciation for logic. In recommendation number 14, as we have pointed out above, it refers to the need of a doctor not just to know all the books written on medicine, but to also understand this in relation to the foundations of natural science. These foundations point to the demand for building a philosophy of nature that Israeli based on a conception of reality. He was able to find the information for it not just from Muslim authors, but other philosophers, and even in medical texts. To this he adds that the doctor must be able to manage the rules of logic, as an instrument for preserving the profession by unmasking false physicians:

"Just as you need to read all the books composed on the art of medicine, so you will need to understand their contents in terms of the fundamentals of natural science, because medicine

[32] Lola Ferre, "Medicine through a Philosophical Lens: Treatise of Isaac Israeli’ Books on Fevers", p. 111.

(In press).

[33] Lola Ferre, "Medicine through a Philosophical Lens", p. 128. 
stems from it, and also become proficient in the rules of logic, so that you will be wise in refuting the ignoramuses who walk in the guise of physician, and frighten them from before you, and they shall fear you" 34 .

In addition, in his texts the figure of dialectic and its discourse also appears, sometimes explicitly and sometimes implicitly, coming to be the answer to some of his questions, which is the motive that is even the origin of some of Israeli's texts.

It is in the Book of Definitions where he tackles the statute of philosophy to respond to those who criticise that there is more than one definition. According to Israeli, philosophy cannot be defined, because the definition is made up of genre and specific difference, and philosophy doesn't belong to any genre ${ }^{35}$. But it can be described according to name, property or effects, coinciding with the methodology that should govern all research ${ }^{36}$ (whether or not something exists, what it is, what its qualities are and what its purpose is). The different descriptions would be, then, aspects distinct from philosophy: love of wisdom; assimilating, according to human capacity, not God but the actions of the Creator, and man's self-knowledge. He who wishes to acquire true knowledge of himself, of his corporeality and spirituality, has come to know the existing realities and with this, the universe, and because of this, man is a microcosmos. His purpose is to investigate with his reason to understand the truth of things and act according to this knowledge, with justice and rectitude, pursuing good and avoiding evil. In this way he will merit the reward of his Creator: the union which constitutes the form of the intellect, wisdom. He who achieves this type of perfection is worthy of calling himself "philosopher".

Philosophy is, then, maximum knowledge and also maximum dedication, as it perfects man and puts wisdom within his reach. In this respect the scarce presence of Judaism on this matter, and the work of Israeli in general, is surprising. He doesn't base his argumentation on his faith, and doesn't enter into theological questions or deal with the basis of the precepts, as for example Maimonides will do later. His monotheism is inserted into the Neoplatonic system, a metaphysics of light and a philosophy of nature, a physics, and transcends the ascribing to a specific faith, as he also writes in Arabic.

The sources note that, upon being questioned why he had no children, Israeli responded that his books would grant him the recognition and fame that no child could obtain for him. And amongst these books he alluded to the Book of Elements ${ }^{37}$, a text of philosophy that includes an excursus on the double discourse of the ancients and in which the topic of prophecy appears. Hippocrates and Galen would have followed this methodology, that of double discourse, attributing it to the philosophers, who would use it in the face of the intellectual and moral diversity of man. The first level would be the common man, impetuous and of hard understanding; the second - in which the true message would be - would be for the philosophers: it is aimed at the intellect and demands training,

[34] Ariel Bar-Sela, "Isaac Israeli's fifty admonitions to the physicians", in Journal of the History of Medicine and Allied Sciences, 17:2 (1962:Apr.) p. 253.

[35] In Topics I, 4, 108 to 31, Aristotle defines genre as that which predicates essentially from many that differ specifically. Every substance implies an essence. Essence is the group of the fundamental notes of a thing. Such notes will be genre and difference. Genre is the undetermined part, but which can be determined, from essence. The difference is that which distinguishes one thing from another, but starting from a common shared base.

[36] In the Book on Fevers, he also applies them to medicine, which suggests that the philosophical methodology is the usual research method in all fields of knowledge.

[37] A. Altmann and S. M Stern, Isaac Israeli: a neoplatonic philosopher, p. xix. 
investigation and effort ${ }^{38}$. The development of this idea later gives rise to another double discourse that will end up imposing itself against that of the levels of philosophy: the difference between philosophy, which speaks to the elite, and religion, which speaks to the people. And we will find its development at least until the 19th century in an author such as Arthur Schopenhauer who already starts out from an atheist paradigm, and for whom the concept of revelation already has other connotations ${ }^{39}$.

Returning to Israeli, he provides, however, an additional reason on double discourse: philosophers imitate the working of the intellect. In modern words, Israeli would be saying that they imitate the way in which the brain processes information. According to our author, the information of the senses, especially vision, passes through common sense and then fantasy, situated in the anterior ventricle of the brain. This transforms matter into intermediate representations between the sentient and the abstract. At this level a basic understanding, an initial pre-reflexive assimilation, would take place. Thus, once the information is captured, and only then, will it be possible to extract its intelligible or spiritual meaning, again via images, of analogy and allegory, as "the shape of something corporal and communicated by the senses is better printed on the anterior ventricle of the brain, due to its proximity to the corporal sense" 40 . From one moment to the other representations, images are fundamental.

But in turn, the intellect imitates revelation. The prophet is the intermediary between the Creator and his creatures, as the intellect is between God and the soul. Part of the prophet's message will be evident, but another part will need interpretation. To this end, God transmits a message to some in an unequivocal form in order for them to interpret it and be teachers to those who cannot understand. However, the prophet appears in the work of Israeli as a trustee of the revelation and as a receiver of the Book, but not as an interpreter or educator of man. Interpreters are the moral teachers and researchers of $\operatorname{truth}^{41}$, the philosophers, who also know how the intellect works. Philosophy, as he put forward in the Book of Definitions, imitates the acts of God; in this case it is revelation. Israeli supposes that prophets and philosophers achieve the same knowledge, which deals with both figures and leaves their differences and the need for religion in the air, which in an author such as Alfarabi will be better for the people. But he also lets us see that, although all men are obliged to search for and examine the truth, and he himself inclines towards philosophy, the objective is to sustain a dialogue, which calls together everyone, to clarify the $\operatorname{truth}^{42}$ and put it into practice.

[38] This double discourse thesis will repeat itself throughout the history of philosophy. It appears in the Arabic context, for example, in Alfarabi, in Avicena, in Averroes, but also - now in a secularised context - in an author such as Schopenhauer in relation to the usefulness of philosophy and religion to respond to the metaphysical necessity.

[39] "There is no more revelation than the thoughts of the wise; although, in accordance with the destiny of all that is human, these thoughts are subject to error and are often sheathed in astonishing allegories and myths, and so they are called religions. Therefore, at this level it is not important if one lives and dies trusting in one's own thoughts or other thoughts, as one always trusts in simple human thoughts and opinions. Notwithstanding this, men normally have the weakness of trusting more in others who claim to have supernatural sources than in their own mind. But faced with the enormous intellectual inequality between man and man, we could easily consider that the thoughts of one are to a certain extent like revelations to another (Arthur Schopenhauer, Parerga and Paralipomena II. "On Religion". Translation, introduction and notes by Pilar López de Santamaría, Trotta, Madrid, 2009, p. 374.

[40] An excerpt from the Book on the elements, pp. 134-5.

[41] I. Israeli, An excerpt, p. 140.

[42] I. Israeli, The Mantua Text, § 6, p. 125. 
David Shatz has pointed out that the theory of prophecy is a window into Medieval epistemology which, in turn is founded on Medieval metaphysics. As Altmann indicates, Israeli does not expound a developed theory on prophecy. References in this regard, Neoplatonic in nature, appear in the Book of Definitions, in the second chapter of the Book of Elements, and in the three types of prophecy established by his disciple Dūnash ibn Tamīm in his commentary in the Book of Creation which we suppose come from a distinction already made by his teacher ${ }^{43}$. In the case of the disciple the three types refer to: prophecy through a voice created by God and heard by the individual; the prophetic vision or dream, which would be a higher level; and the highest level, which would be that reached by Moses. Israeli's disciple understands it as an ecstatic experience, a mystic union, being in the case of Israeli specified as inspiration or possession through which the soul of the prophet becomes the body of God ${ }^{44}$. Also according to Altmann, in this context, prophecy, there wouldn't be a difference for Israeli between the philosopher and the prophet:

"There is no sharp dividing line between prophet and philosopher. Both share in the common task of guiding mankind towards the same goal: both are concerned with the ascent of the soul, its liberation from the bondage of matter, and its eventual union with the supernal Light" ${ }^{\prime \prime}$.

The difference between both, between philosophers and prophets, will initially reside in the process. In the case of prophets they do not require advanced training, or investigation, reflection, time or effort, as it is a divine gift. Israeli underlines how philosophers - with their double discourse method - consciously imitate how the intellect works when processing information, that is, they base themselves on their theorisation on the working of knowledge. In addition, he even indicates a cerebral location for the capacity to create images. We can also point out here a certain intention to develop a deep naturalist approach, to the extent that the aim is to articulate a rational explanation based on natural causes, on human faculties. We could even say that Israeli would form part of the prehistory of which is today still a very emerging field in philosophy, or rather interdisciplinary: that of neurophilosophy or, moreover, neurotheology.

And more. Beyond the prophetic aspect, Israeli points to a special logic, based on the capacity to argue evoking images, a universal channel that facilitates the understanding of a complex idea or promotes the carrying out of an action. With this he furthermore brings the philosophical discourse closer to other spheres to which he has traditionally been opposed. In this sense, our author would form part of a long tradition in which philosophy converges, to a certain degree, with inspiration and artistic creation. In the analysis of his work the importance of al-Kindi has been highlighted, but especially in relation to the Book of Definitions. However, it is also worth exploring the harmony with the Alfarabi position as regards the relationship between philosophy and religion. López Farjeat has referred to one of the achievements of this tradition, the contemporary of Israeli, Alfarabi, and to his interest - following the thread of the Poetic- in poetic reasoning: a deduction, image, intuition with the same strength as an analogy. Poetic discourse ${ }^{46}$ does not operate with evident premises. It

[43] Altmann, "The role of prophecy", in A. Altmann and S. M Stern, Isaac Israeli: a neoplatonic philosopher p. 209.

[44] Altmann, "The role of prophecy", p. 215.

[45] Altmann, "The role of prophecy", p. 209.

[46] "Poetic discourse consists of similes and comparisons, whose rational meaning we analyse by showing that they are the conclusions of a kind of syllogism - of argument by example- that has an imaginative universal or particular as its main premise and the first figure syllogism as its ultimate form (...) Imagination constructs 
pursues representation and the suggestion of something, an idea, an action, through an image that makes us comprehend, but also leads us to act. For the non-reflexive person, understanding through images sometimes causes reflection. For the reflexive person it is also useful - if not necessary -, as "imaginative suggestion precedes his reflection" and accelerates his action. The imagination imitates: "It is capable of searching for new images to create representations of the unknowable via a sensitive path"47.

As Pérez Gandía has also indicated, the theorisation that Alfarabi carries out on the wisdom of the prophets, a topic also of great interest to the rest of the Arabic philosophers of the classical era, leads him to

"expand on the logic of Aristotle with rhetoric (through which the truths are made accessible to all) and the poetic (which allows the suggestion, through images and metaphors, of the ultimate metaphysical truths)",48.

\section{The hypothesis of Paredes Gandía is that}

"one of the sources of these 'such European' ideas, that attempt to define the role of religion in a lay state and a secular society, would be in the Muslim philosophers, which they would transmit, via Maimonides, to Spinoza, going from him to German idealism"49.

What we sustain is that in our author we would have, in this sense, one of the milestones of the process.

In all of these contexts, prophecy would not consist as much in anticipating the future as in "bringing a message of a higher order or reality to a specific human collective", as indicated today by Seyyed Hossein Nasr And it is not always an order that is legal, ethical or of spiritual significance. It can also be sapiential or a message from another level of the conscious $^{50}$ as occurs in knowledge through images. Furthermore, and following the thread of prophecy, Israeli tends to explain, as do so many authors, the origin of knowledge as a divine gift. What he calls "intellectual precepts", the laws of reason, he presents as an example of prophetic emanation. It will be centuries before they are situated in the subject and his authorship is recognised. An important fact is the gradual tendency, in the field of Arabic philosophy, not just to be interested in the whole process of knowledge, but to interpret the different intellects as stages of a unitary and internal process.

Another important contribution is that of ibn Paquda, a Jewish philosopher from Zaragoza in the 11 th century. The tension between the philosopher and the man of religion is

the associated representations which are present in examples. Therefore, first, the resulting statement can never be actual but must be only potential; and, second, because it is only an association of particulars, it cannot be strictly deductive and based on universal premises but must succeed only on the basis of representations. Yet, third, because the subject must understand the associations in order to acquiesce to their meanings, the statement is categorical and its inferential structure «has the force of a syllogism»" (Salim Kemal, The philosophical Poetics of Alfarabi, Avicenna and Averroës. The Aristotelian Reception, Routledge, London and New York, 2010, p. 62).

[47] Luis Xavier López Farjeat, "El silogismo poético y la imaginación en Alfarabi”, in Tópicos, 10 (2000), p. 108.

[48] José Antonio Paredes Gandía. Introduction to Abu Nasr Al-Farabi, The Book of Letters. The origin of words, philosophy and religion. Trotta, Madrid, 2004, p. 29.

[49] José Antonio Paredes Gandía, Introduction to Abu Nasr Al-Farabi, p. 36. "The philosophical origin of Europe would be, then, in its capacity to distinguish reason and faith, world and spirit, Church and State, having received the first impulse behind this distinction of the Muslim thinkers, although the solutions ended up being original from the Christian world (Introduction to Abu Nasr Al-Farabi, p. 37).

[50] Seyyed Hossein Nasr, Islamic philosophy from its origin to the present: philosophy in the land of prophecy, State University of New York Press, New York, 2006, pp. 1-9. 
renewed in The Duties of the Heart, which seems to be a text of exclusively pious reading. It calls intellectual precepts "duties of the heart". They are principles and foundations, conditions of possibility, practical and theoretical in nature. They always oblige us, "while we have use of reason". Ibn Paquda indicates that it is necessary to bring them into the light, tackle their reconstruction, his "science of the duties of the heart" being more an exercise of transcendental reflection not carried out up to now. The path of reason, which for him is also wider than the strictly logical, is the obligatory one where it is possible ${ }^{51}$, as along it are the most noble gifts awarded to man ${ }^{52}$. And only he who follows his reason can have selfdetermination. In fact, the only ones who would understand religion (its concepts, its foundations) are the prophet and the philosopher. The rest - he comes to say - adore something that is not $\operatorname{God}^{53}$. But only in the philosopher would the desired correspondence be given between the internal principles and the actions. The problem is that the notion of God that philosophers subscribe to, and which ibn Paquda shares, is "pure solitude separated from everything; individuality which completely excludes anything similar and communion" 54 . But not just this: Paquda has no problem in recognising that in reality philosophy does not offer a conclusive answer for everything it deals with, including the science of duties of the heart itself ${ }^{55}$. And however, the knowledge of the philosopher is inspired $^{56}$, and as long as it doesn't go against the foundations of faith (and the author does not specify more on this), a philosopher can and must continue with his reflections ${ }^{57}$. Moreover, to paraphrase the Ecclesiastes about the wise: their words are a healthy stimulus because they rouse: they endure in the soul like hard nails, and always have something to say to us. In any case, he who is truly prepared for investigating the science of the heart is the philosopher.

\section{PROPHETS OR PHILOSOPHERS?}

We at least know because of one letter that Maimonides knew the work of ibn Paquda and because of another that he didn't appreciate Israeli's Book of Elements. And in some way the Guide for the Perplexed will respond to both. It will attempt to dilute the tension between philosophy and religion, rationalising Judaism. The fight against the perplexity of the heart runs through the Guide for the Perplexed. Maimonides is concerned about the anthropomorphism of religious language but defends its use for the masses, that nothing can be conceived if it is not based on corporeality, although deep knowledge should be in any case vetoed for the uneducated and must even not be completely revealed to just any wise man. Nevertheless, he does not comment on Israeli's interest in the potent meaning

[51] Ibn Paquda, Los deberes de los corazones, Fundación Universitaria Española, Madrid, 1994, p. 14.

[52] Ibn Paquda, Los deberes, p. 3.

[53] Ibn Paquda, Los deberes, p. 29.

[54] Ibn Paquda, Los deberes, p. 41. 'God is for us and for his very essence the most hidden of the hidden and the furthest that there can be (...). If you wish to reach his essence or compare it with anything created his existence will fade from us (Ibn Paquda, Los deberes, p. 57).

'despite his Neoplatonic concept of the unity of God (...) Bahya did not attempt to bridge the gap between God and reason by means of ascetic contemplation. Nor did accept a sphere of psychic intermediaries between God and man' (Ibn Paquda, The Book of Direction to the Duties of the Heart (from the original Arabic version of Bahya Ben Josepf Ibn Paquda's al-Hidāya ilā Fara 'ị̂ al-Qulūb), Routledge \& Kegal Paul, London, 1973, p.8).

[55] Ibn Paquda, Los deberes, p. 51.

[56] Ibn Paquda, Los deberes, p. 109.

[57] Ibn Paquda does not subscribe to the reservations for example of Maimonides regarding the teaching of physics and metaphysics. 
of images in philosophical discourse, despite the importance of imagination in his analysis of prophecy.

Furthermore, in chapters 32 to 47 of the second part of the Guide and the end of the third part we come across a theory of prophecy to return the primacy to the prophet. $\mathrm{He}$ defines the prophet as an emanation of God through the active intellect initially on the first rational faculty and then on the imaginative faculty. This acquires prominence, for example, during sleep, when it is not occupied with the transformation of information from the senses. Thus, there is a sudden chance of inspiration common to this and to prophecy. It is the highest degree of perception to which man can aspire and requires a series of conditions: perfection of the moral and rational qualities of the imagination, and a constant orientation of the individual towards knowledge.

According to Maimonides, this divine emanation is rationality, that which allows us to think. And to that depends the individual superiority of our intelligences. If the emanation occurs only on the rational faculty, due to its scarcity or a defect of the imaginative faculty, we have speculative sages. If the emanation occurs in both faculties, we have prophets. If it only happens with the imagination, we have statisticians and legislators, next to miracleworkers and frauds. Furthermore, sometimes the emanation reaches an individual in such excess that it allows him to create works and teach. Without it there would be no scientific books, and prophets wouldn't be concerned with Humanity. But Maimonides always adds a requisite: the prophet must be chosen by God. Only Moses would have been a prophet par excellence, because the active intellect emanated on him directly, without intervening in the imagination.

With regard to the above reflection on prophecy, Maimonides specifies what love of God consists in, the objective of the believer but also of the "science of the duties of the heart" and of philosophy in Israeli. The love of God would go further than the fulfilment of precepts, of the knowledge of the intelligible and even of virtue. But this aspiration, this passion, faces a great hurdle linked to the total heterogeneity of the object of love and which is emphatically expressed: "Your thoughts are not my thoughts, nor are my paths your paths", that is, to the insurmountable abyss between God and Man. Despite this, in the scene of Sinai, although God denies Moses, the perfect prophet, the knowledge of his essence, $\mathrm{He}$ promises to show him his "back" understood as such to be his footprints on the world, with which it would be possible to imitate His behaviour. As Maimonides points out in the same text, according to Jeremiah, that which can glorify man is to know the acts of God, who would have said: "I am Yhwhm, and I act with compassion, justice and righteousness on the earth". Imitating God would be to know and follow this model: His benevolence, justice and equity. And to this moral orientation another would accompany it in politics: "He who governs a State, if a prophet, must accommodate these attributes". The three middot must be the principles of his political action, such as Moses himself decided to govern his people. Middot mean "characteristics and nearly all of them allude to God's compassion. The script limits them to 13 because they are those relating to the government of men. To imitate God, actions must emanate from the leader "in accordance with moderation and justice", not from outbursts of passion. There must not, then, be emotional involvement, rather, "because it follows to do so", and "considering the great utility" for the masses. In this imitation dispassionate as it is divine - and which would guide the moral and the political, constant thought is focused on God to such an extent that Maimonides began classifying it as passion. We have the situation, then, where the tension between religion and philosophy is resolved in the imitation of the attributes of God's action. And here would be the ultimate indication 
for the perplexed, the deepest principle of the worship of the heart and also the final fulfilment of "Hear, O Israel". He has Moses, the Prophet, as a model. Centuries later, an author such as Spinoza will end up encapsulating in it, in charity and justice, the most important message of the Scriptures and in the common goal of all men, believers or not, and in a free State $^{58}$.

Ibn Paquda and Israeli ended up establishing the model in the philosopher, also perplexed in the first case, as I have indicated, and in the second, that of Israeli, to a certain point artistic, for his work with images, in essence a literary and creative resource not exempt from scientific knowledge, in the era of the psychology of the soul. In both cases, in ibn Paquda and in Israeli, both the philosopher and the philosopher with artistic qualities are merely men, humans. In the case of Maimonides, it shouldn't be forgotten that God lacks what we would call our moral qualities, although "He carries out actions similar to those that in ourselves originate from them". His attributes of action are attributes indicative of a perfection, but by analogy with the model that is essentially behind although not because of this it stops being valuable, extremely valuable: that which humanity has considered as ideals of perfection.

\section{CONCLUSION}

The scarce information available on the life of Israeli, the total lack of details on his training and the texts that have reached us, not all of which are mentioned in the sources and some of them being incomplete, do not allow us to make an exact assessment, and less so definitive, of his work. In addition, the author's style, sometimes allusive, completely unsystematic, and basically imprecise, together with the use he makes of the language and the Neoplatonic topics and philosophemes, are an added difficulty for getting close to and characterising his thought. This has been approached, above all, from the point of view of his possible sources and has been characterised as a reading within the context of Neoplatonism and, in essence, is eclectic and lacks originality.

Isaac Israeli, for his part, considered that his philosophical work, especially the ideas developed in the Book of Elements, was also worthy of later recognition and he entrusted his memory to it. Whether this anecdote is real or not, an attentive reading of the philosophical texts that have reached us does not reveal a mere eclectic or compiler. The texts reveal a physician with a global conception of knowledge, of the search for a basis for medicine via the philosophy of nature and Neoplatonic and Aristotelian metaphysics. But they also reveal a philosopher who participates in the great debates of his time: the relationship between philosophy and revelation and the nature of the human intellect. For both debates, however, he lacked both the Jewish precedents and vocabulary in Arabic, which makes his contribution more valuable, meagre as it may be. But the most outstanding feature of Israeli's entire project is that, more than a Jewish author, he appears as a thinker who incorporates Greek thought and tries to conciliate it with monotheism. And the latter, monotheism, is perhaps the most important, in the sense that in his thinking he overcomes adherence to a specific faith, and could even be called a philosopher of the three cultures. Not in vain does he state that all men have the obligation to seek the truth, especially the most intellectually gifted; that philosophers, prophets and the wise must do it with dialogue amongst themselves and with others; and that the truth must be put into practice.

$\left[{ }^{58}\right]$ Spinoza, Tratado teológico-político [Theological-Political Treatise]. Translation, introduction, notes and indices by Atilano Domínguez. Alianza Editorial, Madrid, 2012, pp. 70, 316-317, 391. 


\section{BIBLIOGRAPHY}

[1] Altmann, Alexander, Stern, Samuel Miklos, Isaac Israeli: a neoplatonic philosopher of the early tenth century. His works translated with comments and an outline of his Philosophy, Oxford University Press, Oxford, 1958.

[2] Bar-Sela, Ariel, "Isaac Israeli's fifty admonitions to the physicians", in Journal of the History of Medicine and Allied Sciences, 17:2, (1962:Apr.), pp. 245-257.

[3] Ferre, Lola, "Medicine through a Philosophical Lens: Treatise of Isaac Israeli' Books on Fevers" (In Press).

[4] Fried, Salomon, Das Buch über die Elemente. Ein Beitrag zur jüdischen Religionsphilosophie des Mittelalters, Verlag von J. Kauffmann, Frankfurt a. M, 1900.

[5] Guttmann, Jacob, Die philosophischen Lehren des Isaak ben Salomon Israeli, Aschendorffsche Verlagsbuchhandlung, Münster i. W, 1911.

[6] Guttmann, Julius, Philosophies of Judaism. A History of Jewish Philosophy from Biblical Times to Franz Rosenzweig. Introduction by R. J. Zwi Werblowsky. Translated by David W. Silverman, Schocken Books, New York, 1976.

[7] Harvey, Steven, "Did Maimonides' letter to Samuel ibn Tibbon determine which philosophers would be studied by later Jewish thinkers?", in The Jewish Quarterly Review, Vol. LXXXIII, (july-october, 1992), pp. 56-57.

[8] Husik, Isaac, A History of medieval Jewish philosophy, The Macmillan Company, New York, 1918.

[9] Ibn Paquda, The Book of Direction to the Duties of the Heart (from the original Arabic version of Bahya Ben Josepf Ibn Paquda's al-Hidāya ilā Fara'ị̆ al-Qulūb), Routledge \& Kegal Paul London, 1973.

[10] Ibn Paquda, Los deberes de los corazones, Fundación Universitaria Española, Madrid, 1994.

[11]Kemal, Salim, The philosophical Poetics of Alfarabi, Avicenna and Averroës. The Aristotelian Reception, Routledge, London and New York, 2010.

[12] Lomba, Joaquín, “The agonies of 'eurocentrism' ”, in Éndoxa: Series Filosóficas, 12, (2000), pp. 8283.

[13]López Farjeat, Luis Xavier, "El silogismo poético y la imaginación en Alfarabi", in Tópicos, 10 (2000), pp. 97-113.

[14] Nasr, Seyyed Hossein, Islamic philosophy from its origin to the present: philosophy in the land of prophecy, State University of New York Press, New York, 2006.

[15] Paredes Gandía, José Antonio, Introduction to Abu Nasr Al-Farabi, The Book of Letters. The origin of words, philosophy and religion, Trotta, Madrid, 2004.

[16] Rudavsky, Tamar M., "Medieval Jewish Neoplatonism", in Daniel H., Frank and Oliver Leaman (eds.), Routledge History of World Philosophies. Vol. II: History of Jewish Philosophy, London and New York, Routledge Press, 1974.

[17] Schopenhauer, Arthur, Parerga and Paralipomena II. "On Religion". Translation, introduction and notes by Pilar López de Santamaría, Trotta, Madrid, 2009.

[18] Sirat, Colette, A History of Jewish philosophy in the Middle Ages, Cambridge University Press y La Maison des Sciences de l'Homme, Cambridge, 1977.

[19] Spinoza, Tratado teológico-político [Theological-Political Treatise]. Translation, introduction, notes and indices by Atilano Domínguez, Alianza Editorial, Madrid, 2012.

[20] Stroumsa, Sarah, Dāwud ibn Marwān al-Muqamis's Twenty Chapters ('Ishrūn Maqāla). Études sur le judaïsme médiéval XIII, Brill, Leiden, 1989.

[21] Valle, Carlos del (ed.), Letters and testimony of Maimonides (1138-1204). III Letter of R. Shemuel Ibn Tibbón. Publicaciones del Monte de Piedad y Caja de Ahorros de Córdoba Córdoba, 1989.

[22] Veit, Raphaela, Das Buch der Fieber des Isaac Israeli und seine Bedeutung im lateinischen Wester. Ein Beitrag zur Rezeption arabischer Wissenschaft im Abendland, Franz Steiner Verlag, München, 2003.

[23] Yabri, Mohamed Abed, El legado filosófico árabe: Alfarabi, Avicena, Avempace, Averroes, Abenjaldún: Lecturas contemporáneas, Trotta, Madrid, 2006. 